Note: This is a pre-copy-editing, author-produced PDF of an article accepted for publication in Drugs: education, prevention and policy following peer review. The definitive publisherauthenticated version [Butler S (2006) Tipping the Balance? An Irish perspective on Anderson and Baumberg, Drugs: education, prevention and policy, 13(6), 493-497] is available online at http://www.informaworld.com/smpp/content $\sim \mathrm{db}=a$ all content=a762372495

\title{
Tipping the Balance? An Irish perspective on Anderson and Baumberg
}

\author{
SHANE BUTLER \\ Addiction Research Centre, School of Social Work \& Social Policy, Trinity College \\ Dublin
}

Published in Drugs: education, prevention and policy, 13(6), 493 - 497

Copyright: Informa Healthcare

\section{Introduction}

Although Ireland did not qualify for the World Cup and political realignments and new voting systems appear to have terminally damaged our prospects of ever winning the Eurovision Song Contest again, the evidence presented by Anderson and Baumberg (2006) that we still excel when it comes to drinking was greeted with no great enthusiasm on the publication of this report in June 2006. The media in Ireland highlighted two statistics from this report - one showing that the Irish spend more of their income on alcohol than any other European country and another that the Irish are the most frequent 'binge' drinkers in Europe - while also drawing attention to the figures which put the Irish in third place, behind the Czech Republic and Luxembourg, in terms of annual per capita consumption.

From an Irish perspective, perhaps the best place to start in attempting to assess the importance of this comprehensive report on alcohol in Europe is with the immediate responses of the main protagonists, the drinks industry and the public health lobby. The chairperson of Alcohol Action Ireland, a national organization which lobbies for the implementation of an integrated, public health approach to alcohol, was quoted as saying:

Please use the following citation: Butler S (2006) Tipping the Balance? An Irish perspective on Anderson and Baumberg,. (Author postprint) in Drugs: education, prevention and policy, 13(6), 493 - 497 [Accessed: (date) from www.drugsandalcohol.ie] 
'This report points the way. Action needs political courage as we are dealing with not just an irresistible pleasure but massive vested interests' (Ireland On-Line, June 1, 2006). Equally quick off the mark, however, was the Drinks Industry Group of Ireland which took Anderson and Baumberg to task, arguing: that the Irish statistics being discussed were out of date; that the proportion of disposable income spent on alcohol primarily reflected the high levels of alcohol taxes in this country; and that the report 'was another attempt by the anti-alcohol lobby to demonise the alcohol industry and pressure policymakers into introducing draconian measures to tackle a serious but limited problem' (The Irish Times, June 2, 2006). What these responses indicate is that, in terms of a national debate on alcohol policy, the battle lines have already been well and truly drawn; what would seem most useful analytically, therefore, is to sketch out some detail of this ongoing national debate and then assess the potential impact on it of Anderson and Baumberg, in terms of their report's content and provenance.

\section{Alcohol Policy Debate in Contemporary Ireland}

Continuing policy debate about alcohol has been a feature of Irish life for the past decade (Butler, 2002; 2003), and to a large extent the issues at stake here are the same as in other countries; for instance, the controversy surrounding the Alcohol Harm Reduction Strategy for England, in which the state was accused by public health interests of an unwillingness to challenge the drinks industry by implementing evidence-based strategies (Babor, 2004; Room, 2004), is practically identical with that which has been taking place in Ireland. There are, however, different overtones to the Irish debate because it is taking place in the context of the so-called 'Celtic Tiger', the popular description of the first significant and sustained period of economic affluence enjoyed by the Irish state since its establishment in 1922. The causes and broader significance of this economic boom which started in the early-1990s have been much debated (Sweeney, 1999; Allen, 2000; Kirby, Gibbons and Cronin, 2002) but, regardless of what conclusion one reaches on these questions, it is clear that the relevance of the Celtic Tiger for Irish alcohol consumption goes far beyond narrow economic factors. It is not just that unprecedented levels of personal disposable income have facilitated the creation of a permanent party atmosphere, allowing the Irish to indulge their taste for alcohol as never before. On a

Please use the following citation: Butler S (2006) Tipping the Balance? An Irish perspective on Anderson and Baumberg,. (Author postprint) in Drugs: education, prevention and policy, 13(6), 493 - 497 [Accessed: (date) from www.drugsandalcohol.ie] 
wider cultural level, this economic success reflects an openness to globalized industry and a commitment to enhanced personal freedoms which formed no part of the country's self-image during the early decades of self government. The vision of Ireland espoused during the 1940s by Eamon De Valera, the dominant political figure in independent Ireland for its first half-century, was one of social and economic isolationism coupled with communal religiosity and personal austerity. While this idyll, with its references to 'frugal comfort', 'athletic youths' and 'comely maidens' (Brown, 2004, 134) still looms large in Irish consciousness, it is more likely to be referred to nowadays as parody rather than as constituting a serious philosophical challenge to the neo-liberalism which underpins the Celtic Tiger. It would appear to be the case that in all developed countries the state mediates uneasily between the public health bloc and the drinks industry; in Ireland this uneasiness is especially pointed, in the sense that state challenges to the profitability of the industry or paternalistic attempts to reduce alcohol consumption levels amongst the citizenry smack of the bad old days, which people are understandably reluctant to revisit.

In terms of its content, the Anderson and Baumberg report makes no major new contribution to the Irish alcohol debate. Detailed accounts of the dramatic increases in alcohol consumption which have taken place here during the boom years have already been presented in two official health reports from the Strategic Task Force on Alcohol (2002; 2004), and an earlier comparative study (Ramstedt and Hope, 2005) conclusively demonstrated that our high levels and risky patterns of consumption have pushed us to the top of the European league tables. Similarly, research reviews indicating which strategies work and which don't work have already been presented, not just in the previously mentioned reports of the Strategic Task but also in an earlier report, National Alcohol Policy - Ireland (1996), which drew heavily on one of the World Health Organisation (WHO) reports, Alcohol Policy and the Public Good (Edwards et al., 1994). Despite these well argued recommendations for the introduction of evidence-based strategies - which would use a combination of fiscal controls, restrictions on public access to retail outlets, tougher drink driving measures and control of alcohol advertising and promotion - the Irish political system has vacillated about implementing measures of

Please use the following citation: Butler S (2006) Tipping the Balance? An Irish perspective on Anderson and Baumberg,. (Author postprint) in Drugs: education, prevention and policy, 13(6), 493 - 497 [Accessed: (date) from www.drugsandalcohol.ie] 
this kind, and to date no integrated, 'cross-cutting' policy structures have been created comparable to those in place to manage illicit drugs. In the absence of an integrated policy system or an agreed philosophical underpinning to the management of alcohol, specific alcohol policy issues have tended to be debated on a case by case basis, with the balance swinging now one way, now another. In early 2005, for instance, a legislative proposal to expand the total number of licensed premises through the creation of 'cafe bars' (based on an aspiration to transform Irish drinking habits into more moderate Continental European drinking habits) was defeated by an unlikely alliance of public health advocates and licensed vintners - the latter being motivated by an understandable wish to defend their existing monopoly rather than by any broader commitment to public health concerns. Towards the end of 2005, however, the Minister for Health and Children abandoned draft legislation, prepared by her predecessor, which was aimed at controlling alcohol advertising and promotion, and instead negotiated a voluntary code with the drinks industry and its advertising companies. And as a final example of this shifting balance, it is worth noting that at present (July 2006) a new road traffic bill which will introduce random breath testing for motorists is making its way through the legislative process.

\section{The European Dimension}

The fact that the content of Anderson and Baumberg's report on alcohol in Europe is already broadly familiar to Irish stakeholders in this policy process does not mean that it is unimportant from an Irish perspective. It would obviously be naive to think that our legislators will carefully make their way through a text in excess of 400 pages in search of evidence upon which to base a comprehensive national alcohol policy, and - as indicated in the quoted remarks of the Drinks Industry Group of Ireland - the industry is likely to raise questions about both the validity of the statistics presented here and their interpretation. What is most important about this report is its provenance: it is a report prepared for the European Commission and, if its overall policy thrust is accepted by the Commission and if it leads to the creation of European structures and processes for alcohol surveillance as it recommends, then it has the potential to tip the balance firmly in the public health direction in Ireland and elsewhere. While not uncritical about the

Please use the following citation: Butler S (2006) Tipping the Balance? An Irish perspective on Anderson and Baumberg,. (Author postprint) in Drugs: education, prevention and policy, 13(6), 493 - 497 [Accessed: (date) from www.drugsandalcohol.ie] 
broader European agenda, the Irish can generally be considered to be 'good Europeans'; it seems realistic to conclude, therefore, that if the Anderson and Baumberg report survives the attacks which the industry will undoubtedly make on it in Brussels and goes on to influence the emergence of a more evidence-based alcohol policy at this level, it will have an important trickle-down effect in Ireland. As a text, this report lacks the elegance of some of the earlier WHO reports on this topic, but in political terms it seems better placed to influence global policy on alcohol.

\section{References}

Allen, K. (2000). The Celtic Tiger: The myth of social partnership in Ireland. Manchester: Manchester University Press.

Anderson, P. and Baumberg, B. (2006). Alcohol in Europe. London: Institute of Alcohol Studies.

Babor, T. F. (2004). Admirable Ends, Ineffective Means: Comments on the Alcohol Harm Reduction Strategy for England. Drugs: education, prevention and policy, 11(5), 361-365.

Brown, T. (2004). Ireland: A Social and Cultural History, 1922 - 2002 (2nd ed.). London: Harper Perennial.

Butler, S. (2002). Alcohol, Drugs and Health Promotion in Modern Ireland. Dublin: Institute of Public Administration.

Butler, S. (2003). Paying the Price for Extended Opening Hours a comment from Ireland. Drugs: education, prevention and policy, 10 (4), 293-296.

Edwards, G. et al. (1994). Alcohol Policy and the Public Good. Oxford: Oxford University Press.

Ireland on Line (http://home.iol.ie/) (01/06/2006). Irish top European spending on alcohol.

Kirby, P., Gibbons, L. and Cronin, M. (2002). Reinventing Ireland: Culture and the Celtic Tiger. London: Pluto.

National Alcohol Policy - Ireland. (1996). Dublin: Stationery Office.

Please use the following citation: Butler S (2006) Tipping the Balance? An Irish perspective on Anderson and Baumberg,. (Author postprint) in Drugs: education, prevention and policy, 13(6), 493 - 497 [Accessed: (date) from www.drugsandalcohol.ie] 
Ramstedt, M. and Hope, A. (2005). The Irish drinking habits of 2002 - Drinking and drink-related harms in a European comparative perspective. Journal of Substance Use, 10 (5), 273-283.

Room, R. (2005). Disabling the public interest alcohol strategies and policies for England. Addiction, 99(9), 1083-1089.

Strategic Task Force on Alcohol (2002). Interim Report of the Strategic Task Force on Alcohol. Dublin: Department of Health \& Children.

Strategic Task Force on Alcohol (2004). Second Report of the Strategic Task Force on Alcohol. Dublin: Department of Health and Children.

Sweeney, P. (1999). The Celtic Tiger: Ireland's continuing economic miracle explained (2nd ed.). Dublin: Oak Tree Press.

The Irish Times (June 2, 2006). Irish spend three times more on alcohol than EU counterparts.

Please use the following citation: Butler S (2006) Tipping the Balance? An Irish perspective on Anderson and Baumberg,. (Author postprint) in Drugs: education, prevention and policy, 13(6), 493 - 497 [Accessed: (date) from www.drugsandalcohol.ie] 